\title{
Fecal NIRS for predicting percent leafy spurge in diets
}

\author{
JOHN W. WALKER, D.H. CLARK, AND SCOTT D. MCCOY
}

Authors are director, Texas Agr. Exp. Sta., 7887 U.S. Highway 87 N, San Angelo, Tex., 76901; animal scientist USDA-ARS, Forage and Range Research Lab., Utah State Univ., Logan, Utah 84322; research technician, USDA-ARS, U.S. Sheep and Experiment Station, HC 62 Box 2010, Dubois, Ida. 83402

Abstract

Research on diet selection is limited by inadequate techniques for determining botanical composition of diets. Our objective was to determine if near infrared reflectance spectroscopy (NIRS) of fecal material could be used to quantify the percentage leafy spurge (Euphorbia esula $\mathrm{L}_{\text {. }}$ ) in the diets of sheep (Ovis aries) and goats (Capra hircus). Fecal material representing diets of known percentage leafy spurge was obtained from feeding trials conducted in 1992 and 1994. In 1992, diets containing $87.5,75,60,45,30$, and $15 \%$ leafy spurge were fed to 20 sheep and 20 goats. In 1994 10 sheep and 10 goats were fed alfalfa hay (Medicago sativa L.) at $0.5 \%$ of their body weight and ad libitum access to leafy spurge hay. Thus, the percent leafy spurge in the diet varied daily. Microhistological analysis was performed on fecal samples from the 1992 trial for comparison with NIRS predictions. Near infrared reflectance spectroscopy evaluations were performed with a scanning reflectance monochromator. Calibrations were done separately for sheep and goats. Samples were divided into calibration and validation sets. Data from the 1994 feeding trial were analyzed to determine the appropriate lag time between diet consumption and fecal spectral characteristics that provided the best prediction. The average of the diet composition 48 and 72 hours prior to the fecal sample provided the best predictions for the 1994 trial. The effect of spectral outliers on prediction accuracy was also evaluated. Spectral outliers were predicted with equal or better accuracy compared to samples that were spectrally similar to the ones from which calibration equations were derived. The NIRS predictions were more accurate than microhistological estimation of leafy spurge in the diet. The final calibration equation had coefficients of simple correlation for validation samples of 0.91 and 0.93 and standard errors of prediction of 4.6 and 4.8 for goats and sheep, respectively. The results of this study showed that NIRS of fecal material can be used to screen large numbers of animals for phenotypic differences in diet selection and for making treatment comparisons.

Key Words: spectral analysis, sheep, goat, microhistological, botanical composition, near infrared reflectance spectroscopy

We thank David Swanson and Shawna Richardson for tochnical assistance in conducting this research.

Manuscript accepted 28 Nov. 1997.

\section{Resumen}

La investigación sobre selección de dietas se ha limitado al uso de técnicas inadecuadas para determinar su composición botánica. Nuestro objetivo fue determinar si la Espectroscopia Infrarroja de Reflexión (EIR) de material fecal podoa ser usada para cuantificar el porcentaje de Euforbio Frondoso (Euphorbia esula L.) en la dieta de borregos (Ovis aries) y cabras (Capra ircus). Se obtuvo material fecal representativo de animales alimentados con porcentajes conocidos de Euforbia Frondoso en experimentos conducidos en 1992 y 1994. En 1992, 20 borregos y 20 cabras se alimentaron con dietas conteniendo 87.5, 75, 60, 45, 30 y $15 \%$ de Euforbio Frondoso. En 1994, 10 borregos y 10 cabras se alimentaron con paja de alfalfa (Medicago sativa L.) a razón de $0.5 \%$ de peso corporal y se les dio acceso a paja de Euforbia Frondoso ad libitum. De esta forma el porcentaje de Euforbia Frondoso en la dieta vario diariamente. En la prueba de 1992 se realizo un análisis microhistólogico en muestras de materia fecal para comparar las predicciones de esta prueba con las de la EIR. Las evaluaciones de la EIR se llevaron a cabo con un scanner de reflexión monocromática. Las calibraciones se hicieron en forma separada para borregos y cabras. Las muestras se dividieron en grupos de calibración y validación. Los datos de la prueba de 1994 se analizaron para determinar el tiempo de rezago entre el consumo y la aparicion de caracteristicas fecales que proporcionaran la mejor predicción. El promedio de la composición de la dieta 48 y 72 horas antes del muestreo fecal proporcionaron las mejores predicciones para la prueba de 1994. También se evaluó el éfecto de los valores extremos sobre la exactitud de la predicción. Los valores extremos se predijeron con la misma o mejor exactitud que las muestra cuyo espectro era similar a aquellas muestras con las que se hizo la calibración. Las predicciones del contenido de Euforbio Frondoso en la dieta fueron mas precisas cuando se uso EIR que cuando se uso la estimación microhistológica. La ecuación de la calibración final para la validación de muestras tuvo coeficientes de correlación simple de 0.91 y 0.93 y errores estándares de predicción de 4.6 y 4.8 para cabras y borregos respectivamente. Los resultados de este estudio muestran que el examen de materia fecal con EIR se puede usar para estudiar diferencias fenotópicas en la selección de dietas y para hacer comparaciones entre tratamientos cuando se requiere usar un gran número de animales.

Diet selection is a key process affecting both the grazing animal's nutrient status and successional processes in plant commu- 
nities. By preferring some plants and avoiding others, ruminants have a profound effect on the competitive interactions of plants and consequently on the structure and function of ecosystems (Archer and Smeins 1991, Belsky 1992). Most of the effect of grazing livestock on plant communities is directly attributable to what and where they graze. A major purpose of grazing systems is to ameliorate the adverse effect of selcctive grazing. However, long term manipulation of diet selection by livestock will depend upon genetic manipulation of the animals or their microbial symbionts (Walker 1995). This is presently done when the dietary habits of the livestock species are matched to the characteristics of the rangeland resource. Livestock foraging behavior has not been directly selected for in the past because an adequate screening procedure for determining diet selection on large numbers of individuals has not been available.

Near infrared reflectance spectroscopy (NIRS) may provide the tool needed to make possible genetic selection for desired botanical dietary selection by ruminant livestock. NIRS has been used to correctly determine the species composition of forage mixtures (Coleman et al. 1985, 1990, Petersen et al. 1987, Garcia-Ciado et al. 1991), root samples (Rumbaugh et al. 1988) and esophageal extrusa (Volesky and Coleman 1996). NIRS has also been used to predict dietary nutrient content of free ranging ruminants based on spectral characteristics of their fecal samples (Brooks et al. 1984, Coleman et al. 1989, Lyons and Stuth 1992, Leite and Stuth 1995). However, NIRS has not been used to predict botanical composition of ruminant diets based on spectral characteristics of fecal material. Our objective was to determine if NIRS of fecal material could be used to quantify the percentage leafy spurge (Euphorbia esula L.) in the diets of sheeps and goats.

\section{Materials and Methods}

This research was conducted at the U.S. Sheep Experiment Station located in Dubois, Ida. Fecal material, representing diets of known percentage leafy spurge, was obtained from feeding trials conducted to investigate factors affecting intake and preference for leafy spurge.

\section{Feeding Trial}

In addition to producing fecal samples for development of NIRS equations, this trial was conducted to compare preference and intake of leafy spurge by sheep (Ovis aries) and goats (Capra hircus). This was a 10 day trial that provided ad libitum access to a ground forage diet consisting of leafy spurge mixed with either alfalfa (Medicago sativa L.) or a grass and straw mix. There were 2 animals of each species on each of 10 diets, for a total of 20 sheep and 20 goats. Diets consisted of 6 levels $(87.5,75,60,45$, 30 , and $15 \%$ ) of leafy spurge. The $60,45,30$, and $15 \%$ concentrations of leafy spurge were formulated by mixing spurge hay with either alfalfa (representing a high quality dicot) or a low quality monocot (a mix of smooth brome (Bromus inermis Leys.) and barley (Hordeum vulgare L.) straw) for a total of 8 diets. Since the leafy spurge hay used in this trial consisted of only $75 \%$ leafy spurge, the $87.5 \%$ spurge diet was formulated by adding pure leafy spurge to the spurge hay. Animals were fed twice daily at 0700 and 1500 hours. Refusals were removed and fecal samples collected once daily at 0700 hours. Fecal samples from the last 3 days of the trial were composited for individual animals for scan- ning and microhistological analysis. Fecal material was analyzed for percent leafy spurge using microhistological procedures by the Habitat Analysis Laboratory at Washington State University. Two slides were prepared for each sample and 25 fields were viewed per slide for a total of $\mathbf{5 0}$ fields. Microhistological estimates of percent leafy spurge in the diet were compared to estimates from NIRS prediction equations.

\section{Feeding Trial}

This trial was conducted to determine preference by sheep and goats for leafy spurge from different origins. Leafy spurge hays used during the study were from 2 sources, Idaho (approximately $80 \%$ leafy spurge) and North Dakota (approximately $50 \%$ leafy spurge). The feeding trial consisted of a 6 day period when intake of leafy spurge hay from a single source was measured followed by a 4 day period when animals had access to leafy spurge hay from both sources.

During the first 6 days of the trial, 10 head each of sheep and goats were individually fed chopped alfalfa hay at $0.5 \%$ of body weight and ad libitum chopped, leafy spurge hay in separate feeders. Five animals of each species were fed Idaho leafy spurge hay and 5 animals of each species were fed North Dakota leafy spurge hay. In addition, 1 animal of each species was fed either Idaho or North Dakota leafy spurge hay with no alfalfa. Animals were offered the leafy spurge hay and alfalfa in adjacent feeders at 0800 hours each day with the position of the 2 feeds (right vs. left feeder) altered daily. Additional leafy spurge hay was fed at 1600 hours if over one half of the leafy spurge hay from the morning feeding was consumed. Feed refusals were collected each morning, weighed and oven dried at $60^{\circ} \mathrm{C}$ for 48 hours for dry matter determination. Fecal samples were collected at 0800 and 1600 hours each day and oven dried at $60^{\circ} \mathrm{C}$ for 48 hours.

At the end of the 6 days, 8 animals of each species were offered both leafy spurge hays in separate feeders for 3 days but no alfalfa hay. Feeds were offered and refusals and fecal samples collected in the same manner as for the first 6 days.

Percent leafy spurge in the diets was calculated daily for each animal based on the amount and composition of the leafy spurge hay offered, amount and composition of leafy spurge hay refused and amount of alfalfa hay consumed. The percentage of leafy spurge in the fed and refused leafy spurge hay was predicted using near infrared reflectance spectroscopy (NIRS). A calibration equation ( $n=167, R^{2}=0.95$, standard error of calibration $(\mathrm{SEC})=7.16$, terms $=5$ ) was developed from samples of known percentages of leafy spurge mixed with other background forages (e.g., alfalfa, grass, straw). The calculated composition of the diet was used as the laboratory reference value for developing NIRS prediction equations. The laboratory data for this trial appear to be less accurate than the 1992 trial because the calculated percent leafy spurge in the diet included error associated with the prediction equation and measurement of intake and refusal.

The 1600 hour fecal sample for each animal was composited with the following morning's 0800 hour fecal sample to represent the fecal output for the previous day. Since passage rate was unknown, fecal samples for each day were assigned to the percentage of leafy spurge in the animal's diet for the 24,48 , and 72 hours prior to when the fecal sample was collected. Averages for the 24- and 48-, 48- and 72-, and 24-, 48-, and 72 hour leafy spurge percentage were calculated to provide a total of 6 dependent variables for each fecal sample. 
Table 1. Efiect of lag time between diet consumption and fecal collection on validation statistics for percentage leafy spurge in diets versus fecal near infrared reflectance spectroscopy (NIRS)-predicted percent dietary leafy spurge for the 1994 feeding trial.

\begin{tabular}{|c|c|c|c|c|c|c|}
\hline \multirow{3}{*}{$\begin{array}{l}\text { Validation } \\
\text { statistics }\end{array}$} & \multicolumn{6}{|c|}{ Hours between diet consumption and fecal collection } \\
\hline & \multicolumn{3}{|c|}{ Single Diets } & \multicolumn{3}{|c|}{ Average Diets } \\
\hline & $\overline{24}$ & 48 & 72 & $24 \& 48$ & $48 \& 72$ & $24,48 \& 72$ \\
\hline & \multicolumn{6}{|c|}{ 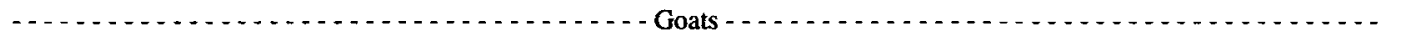 } \\
\hline $\mathbf{n}$ & 23 & 24 & 22 & 20 & 19 & 15 \\
\hline $\mathbf{r}^{2}$ & 0.04 & 0.54 & 0.15 & 0.34 & 0.77 & 0.35 \\
\hline SEP & 10.43 & 7.02 & 14.65 & 7.09 & 4.60 & 7.48 \\
\hline Slope & 0.32 & 0.68 & 0.39 & 0.75 & 1.06 & 0.62 \\
\hline \multirow[t]{2}{*}{ Bias } & -1.09 & 0.25 & -5.73 & -1.25 & 0.26 & -0.53 \\
\hline & \multicolumn{6}{|c|}{ 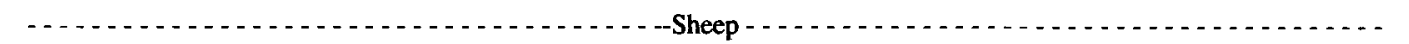 } \\
\hline $\mathbf{n}$ & 26 & 29 & 27 & 23 & 25 & 20 \\
\hline$r^{2}$ & 0.68 & 0.81 & 0.77 & 0.89 & 0.95 & 0.80 \\
\hline SEP & 11.90 & 8.91 & 9.28 & 6.34 & 4.18 & 8.59 \\
\hline Slope & 0.92 & 0.89 & 1.12 & 0.97 & 0.98 & 1.06 \\
\hline Bias & 4.69 & 3.11 & 3.11 & 3.00 & 1.96 & 3.75 \\
\hline
\end{tabular}

$\mathrm{n}=$ Number of observations with outliers excluded.

$r^{2}=$ Coefficient of simple correlation between predicted and actual.

$\mathrm{SEP}=\mathrm{Standand}$ error of prediction.

\section{Equation Development}

Near infrared reflectance spectroscopy evaluations were performed on all samples using a NIR Systems, Inc. (Silver Spring, Md.) ${ }^{1}$ model 6500 , scanning reflectance monochromator. Each sample was packed into sample cells with a near-infrared transparent quartz cover glass and scanned 32 times. Prior to scanning all samples were ground in a cyclone mill to pass a $1-\mathrm{mm}$ screen. Reflected energy $(\log 1 / R)$ was measured, averaged over 32 scans and recorded at 2-nm intervals from 400 to $2,500 \mathrm{~nm}$. A personal computer, interfaced to the monochromator, used ISI NIRS2 version 3 software (Infrasoft International, Port Matilda, Penn.) to collect spectra, develop calibration equations, and evaluate performance of the calibration equation.

Calibration equation development was done using stored NIRS spectra from fecal samples as independent variable reference data and percent leafy spurge in 1992 trial diets, or calculated percent leafy spurge in diets of the 1994 trial for the dependent variables. Calibrations were done separately for sheep and goats. Stepwise regression based on addition of individual wavelengths that maximizc $\mathbf{R}^{2}$ was used because preliminary analysis indicated this method resulted in lower standard errors of prediction (SEP) than other regression methods. Model development was accomplished by evaluating 60 combinations of first through fourth derivative math treatments; wavelength selection from every 4th to every 16 th in increments of 4 ; and scatter corrections of none, standard normal variate and detrend, and weighted multiplicative scatter correction were evaluated for each of the calibration and validation data sets. Equations were evaluated based on minimization of SEP. Standard error of prediction was chosen for equation selection criteria because, as shown below, laboratory reference methods for validating NIRS predictions may be less accurate than NIRS predictions. Thus, in practical application, the opportunity to add additional laboratory reference data will be rare. Similarly, SEP was not corrected for bias because the presence of bias will not be known.

\footnotetext{
Tention of a trademark or proprietary product does not constitute a guarantee or warranty of the product by the USDA and does not imply its approval.
}

Data sets from each trial were split into calibration and validation sets to compute SEP. The 1992 samples were divided into 2 data sets each set consisting of data from one of the replicate animals for each of the 10 diets. The 2 data sets were used for reciprocal calibration and validation. The 1994 data set was divided into thirds (by selecting every third sample) and analyses performed on all possible combinations of using two-thirds of the samples for calibration and one-third for validation (i.e., first and second set were used to predict the third set, etc.).

NIRS prediction equations were calculated following a 4 step procedure to develop and evaluate the equations. First, data from the 1994 trial were tested to determine the appropriate lag time between percentage leafy spurge consumed and fecal spectral data. This lag time was used in subsequent analysis. Next, the NIRS predictions were evaluated for accuracy in predicting an independent internal validation set (i.e., from the same feeding trial that was used to develop the equation), an external validation set, and compared to prediction accuracy of the microhistological technique. Third, the accuracy of prediction of spectral outliers was evaluated. Finally, data from both feeding trials were combined to make a final equation.

\section{Lag Time}

Data from the 1994 feeding trial were first analyzed to determine which lag time between diet consumption and fecal spectral characteristics provided the best prediction (Table 1). The dependent variable with the lowest SEP from this analysis was used for subsequent analysis of NIRS spectra equations.

\section{Equation Validation}

Data for percentage leafy spurge in diets for the 1992 feeding trial were considered most accurate because it did not require estimates of the percentage leafy spurge in fed and refused material. In addition, the same rations were fed for the entire trial so there was no temporal variation in diets. Estimates of percentage leafy spurge in the 1992 diets obtained from microhistological analysis, 1992 feeding trial NIRS prediction equations and 1994 feeding trial NIRS prediction equations were compared to the actual percent leafy spurge in the 1992 diets by regression analy- 
sis to compute the coefficient of simple correlation $\left(\mathrm{r}^{2}\right)$, slope, and bias. The predicted values from the 1992 NIRS equations were computed using the reciprocal calibration validation method discussed above so that predicted samples were not a subset of samples used in calibration development.

\section{Spectral Outliers}

The effect of spectral outliers was analyzed by dividing samples from the 1992 trial into 2 subsets. Samples were grouped into subsets based on the spectral distance of each sample from the average spectrum of feces from the 1994 feeding trial. The 2 groups of samples represented samples that were spectrally similar to the 1994 calibration samples (i.e., Mahalanobis distances (H) less than 3 standard deviations from the mean of the 1994 calibration data set) or spectral outliers (i.e., $\mathrm{H}$ greater than or equal to 3 standard deviations from the mean of the 1994 samples). Equations from the 1994 trial were used to predict the percent leafy spurge in the 1992 diets. Validation statistics to compare predicted and actual percent leafy spurge in the ration were calculated for the 2 groups and compared between these groups to determine if accuracy was affected by differences in spectral characteristics.

\section{Final Equations}

Final prediction equations for use in predicting percentage leafy spurge in the diets of sheep and goats were developed by combining the data from both trials and using the reciprocal calibration validation procedure described previously to determine the math treatments that minimized the SEP. The final equation used the best math treatments on the entire data set. Data for both sheep and goat were combined to compute and evaluate an equation for use when making comparisons between species of animals.

Table 2. Comparison of validation statistics for percentage leafy spurge in diets from 1992 feeding trial based on predictions from microhistological and 2 fecal near infrared reflectance spectroscopy (NIRS)-prediction equations.

\begin{tabular}{lccc}
\hline & \multicolumn{3}{c}{ Prediction method } \\
\cline { 2 - 4 } $\begin{array}{l}\text { Validation } \\
\text { statistics }\end{array}$ & Microhistological & NIRS 94 & NIRS 92 \\
\hline & $\ldots \ldots$ & 20 & 20 \\
$\mathrm{n}$ & 20 & 0.83 & 0.96 \\
$\mathrm{r}^{2}$ & 0.22 & 20.98 & 4.75 \\
SEP & 21.72 & 1.33 & 0.96 \\
Slope & 0.90 & 18.66 & -0.94 \\
Bias & 7.15 & 19 & 19 \\
& 19 & 0.89 & 0.96 \\
$\mathrm{n}$ & 0.32 & 9.91 & 5.01 \\
$\mathrm{r}^{2}$ & 20.23 & 1.30 & 1.06 \\
SEP & 1.02 & 4.02 & 0.73 \\
Slope & 7.64 & Sheep & \\
Bias & &
\end{tabular}

$\mathrm{n}=$ Number of observations used to calculate validation statistics.

$r^{2}=$ Coefficient of simple correlation between predicted and actual.

$\mathrm{SEP}=$ Standard error of prediction.

${ }^{a}$ NTRS 94=Equation developed from average percentage leafy spurge in diet 48 and 72 hours before collection of fecal samples from 1994 feeding trial

NIRS 92- Equation developed from percentage leafy spurge in diet from 1992 feeding trial. Validation samples were not used in calibralion dala set.

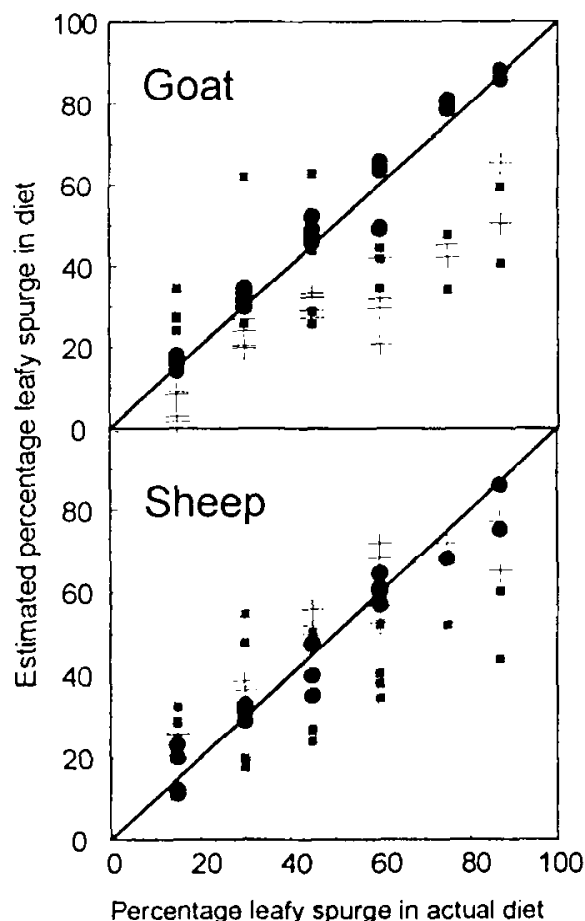

Fig. 1. Percentage leafy spurge in the 1992 diet fed vs. estimated percentage leafy spurge in the diet by microhistological analysis (U), NIRS prediction equation from 1994 feeding trial (+), and NIRS prediction equation from 1992 feeding trial $\left(^{\bullet}\right)$ for goats and sheep. Solid line represents 1:1 relationship.

\section{Results and Discussion}

\section{Lag Time}

The effect of time on internal validation of the 1994 feeding trial is shown in Table 1. For both sheep and goats the best calibration results for single day diets were found between NIRS prediction equations of feces and percent spurge in diets consumed 48 hours earlier. Lyons et al. (1995) reported that NIRS equations of feces collected 72 hours after cattle entered a pasture predicted dietary crude protein and digestible organic matter most accurately. However, their (Lyons et al. 1995) results showed little difference in coefficients of simple determination and SEP between 48 and 72 hours, but slopes were closer to 1 and biases were closer to 0 after the longer lag time. When diet composition was averaged across days validation statistics were best for the average of diets consumed 48 and 72 hours prior to collection of feces. Averaging diets improved the validation statistics compared to diets based on a single day. Coefficients of simple correlation for the regression of percent leafy spurge in the diet and fecal NIRS predictions increased 0.23 and 0.14 percentage units for sheep and goats, respectively and SEP was reduced by about half.

\section{Validation With 1992 Trial}

The precision and accuracy of microhistological analysis and NIRS prediction equations is shown in Table 2. Microhistological analyses were less accurate than either of the NIRS based predictions for both sheep and goats. We believe this difference was due in part to a lack of readily identifiable features in the epidermis of leafy spurge (Bruce Davitt personal communication) and 
Table 3. Effect of spectral outliers on validation statistics derived from prediction of percentage leafy spurge in the diets from 1992 feeding trial using prediction equations developed using fecal samples from the 1994 feeding trial.

\begin{tabular}{|c|c|c|}
\hline & \multicolumn{2}{|c|}{ Mahalanobis distance } \\
\hline & $\mathrm{H}<3$ & $\mathrm{H} \geq 3$ \\
\hline & \multicolumn{2}{|c|}{$\ldots \ldots \ldots$ Goats $\ldots \ldots \ldots$} \\
\hline $\mathbf{n}$ & 7 & 13 \\
\hline$r^{2}$ & .84 & .82 \\
\hline SEP & 10.5 & 10.9 \\
\hline Slope & 1.42 & 1.47 \\
\hline Bias & 18 & 17 \\
\hline \multirow[t]{2}{*}{$\mathbf{H}$} & 2.19 & 6.87 \\
\hline & \multicolumn{2}{|c|}{$\ldots \ldots-\ldots$ Sheep $\ldots \ldots$} \\
\hline $\mathbf{n}$ & 13 & 6 \\
\hline$r^{2}$ & .85 & .97 \\
\hline SEP & 10.2 & 5.8 \\
\hline Slope & 1.34 & 1.20 \\
\hline Bias & -3 & -7 \\
\hline $\mathbf{H}$ & 1.47 & 5.10 \\
\hline
\end{tabular}

$\mathrm{n}=$ Number of observations used to calculate validation statistics.

$\mathrm{r}^{2}=$ Coefficient of simple correlation between predicted and actual.

SEP = Standard error of prediction.

$\mathbf{H}=$ Standardized Mahalanobis distance from average spectrum of calabration data set.

the difference might not be as great for species that are more readily identifiable by microhistological analysis. The 1992 NIRS equation was developed from fecal samples obtained from the same trial as the validation lab data that was predicted. In contrast, the 1994 NIRS equation was developed using fecal samples from a different trial that used different sources of leafy spurge, different sources of other forages, and was conducted in a different manner than the 1992 trial. As expected, the 1992 NIRS equa- tions showed improvements in all measures of precision and accuracy compared to the 1994 NIRS equations. The large bias (18 percentage units) observed when the 1994 NIRS equation was used to predict the 1992 goat diets resulted in a large SEP even though the $r^{2}$ (i.e., 0.83 ) was relatively high. This indicates the importance of evaluating equations based on SEP when developing equations to predict the composition of samples that normally are not available for laboratory analysis. It further shows that NIRS equations may be more accurate at predicting treatment differences than absolute values of the dependent variable. We believe accuracy of these 2 equations represents the upper and lower limits for the use of NIRS equations developed from fecal samples to predict diet composition of leafy spurge.

\section{Spectral Outliers}

When samples are spectral outliers it is recommended that standard laboratory procedures be preformed on the samples to verify the NIRS predicted value. However, when the spectral characteristics of fecal material are used to predict botanical or chemical composition of diets the material being predicted is normally not available for laboratory analysis. Table 3 shows the effect of spectral outliers on prediction of percent leafy spurge in diets fed to sheep and goats. Accuracy of predicted leafy spurge in the diet was the same for goat fecal samples that were spectral outliers compared to samples that were spectrally similar to the calibration data set. For sheep, predictions were better for those samples that were spectral outliers compared to spectrally similar samples. The $r^{2}$ was increased over 10 percentage points and the SEP was decreased about half for sheep samples that were spectral outliers compared to ones that were similar. This indicates that NIRS equations for the prediction of percentage leafy spurge in the diet are robust relative to the spectral characteristics of the sample.

Table 4. NIRS prediction equations using fecal spectra from 1992 and 1994 feeding trials to predict percentage leafy spurge in diets.

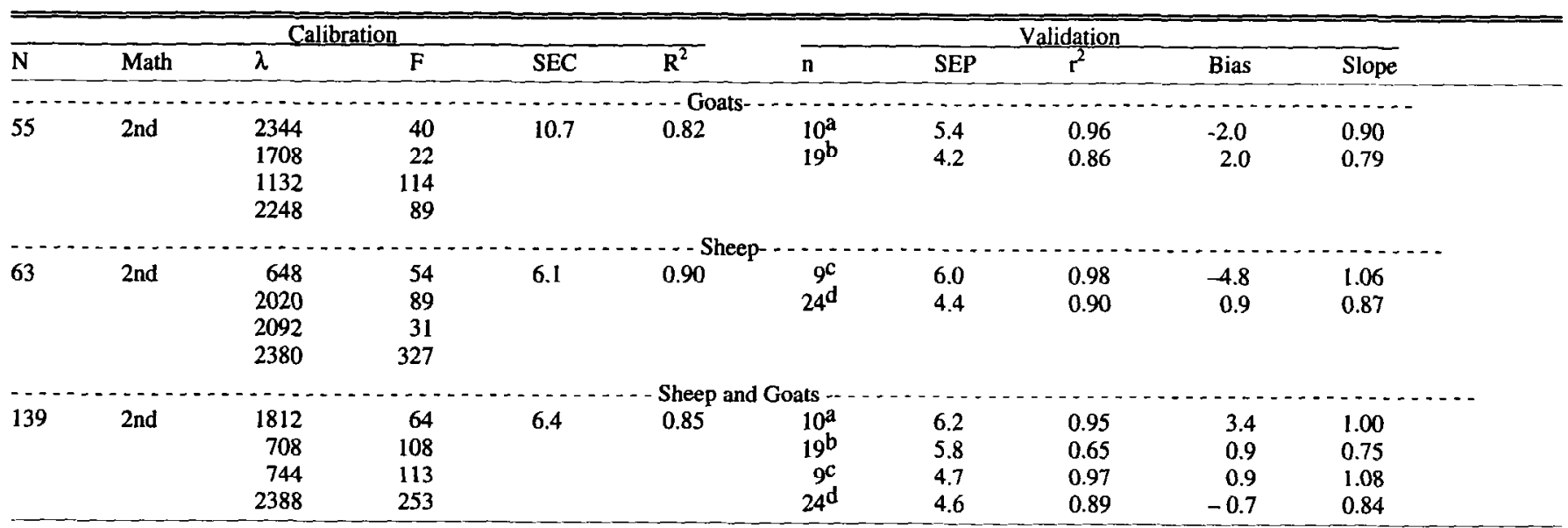

$\mathrm{N}=$ Number of samples used to calculate calibration statistics.

Math= 2nd derivative of $\log (1 / \mathrm{R})$ spectra.

$\mathrm{SEC}=$ Standard ertor of calibration.

$\mathrm{R}^{2}=$ Coefficient of determination.

$\mathrm{SEP}=$ Standard error of prediction.

$\mathrm{n}=$ Number of observations used to calculate vaildation statistics.

$\mathbf{r}^{2}$ - Coefficient of simple correlation.

a - Goat 1992

b - Goat 1994

c - Sheep 1992

d - Sheep 1994 


\section{Final Equations}

The final equations using samples from both feeding trials are shown in Table 4. Calibration statistics were better for the sheep equation than the goat equation. Samples from sheep and goats were combined to determine the ability of a single equation to predict leafy spurge in the diet of both species. The combined equation was intermediate to the sheep and goat equations for calibration statistics.

Validation statistics were calculated for each data set, i.e., goat 1992, goat 1994, sheep 1992, and sheep 1994. Validation $r^{2}$ showed that NIRS prediction of percent leafy spurge in the diet of animals from the 1992 trial accounted for about 10 percentage units more of the variation and had slopes nearer to unity than when the same equation was used to predict composition of the 1994 diets. We believe that accuracy of prediction of the 1994 data is limited by the accuracy of the lab data for this trial as discussed previously. The SEP and absolute value of bias were slightly lower for the 1994 data because the data used for the final calibration contained about twice as many samples from the 1994 trial. Validation statistics for the combined sheep and goat equation showed similar validation statistics for all data sets except that $r^{2}$ was lower for the 1994 as discussed above. There was no apparent systematic bias between species using this equation. Thus the combined equation would be preferred for comparing diets in a study with the objective of making comparisons between sheep and goats

\section{Conclusions}

We interpret these results to show that NIRS analysis of fecal material can be used to predict percent leafy spurge in the diet of sheep and goats and that this technique is more accurate than microhistological techniques for this plant. The prediction of dietary botanical composition based on fecal material compared favorably to previously published results on predicting botanical composition based on the spectral characteristics of the samples. Previously published values for SEP and $r^{2}$ describing the relationship between predicted and actual botanical composition of above ground herbaceous material (Garcia-Criado et al. 1991), roots (Rumbaugh et al. 1988) and esophageal masticate (Volesky and Coleman 1996) were generally between the values for 1992 feeding trial validated against subsets from the same trial and the 1994 feeding trial validated against the equation developed from the 1992 trial (Table 2). Furthermore, within the range of this data set, NIRS predictions of percentage dietary leafy spurge from fecal samples were not affected by spectral outliers with mean $H$ values greater than 5 . The greatest limitation of NIRS prediction of diet composition from fecal samples is the potential for large bias as was seen when the 1994 goat calibration equation was validated with the 1992 samples (Table 2). This indicates that caution should be used when making comparisons that rely on different equations. When interspecific comparisons must be made it would be best to use an equation that predicts both sheep and goat diets.

We believe that NIRS of fecal material can be calibrated to predict other plant species in addition to leafy spurge. Furthermore, this would be an appropriate procedure for screening large numbers of animals for phenotypic differences in diet selection and for making treatment comparisons.

\section{Literature Cited}

Archer, Steve and F. E. Smeins. 1991. Ecosystem-level processes. p. 109-140. In: R.K. Heitschmidt and J.W. Stuth (eds.) Grazing management: An ecological perspective. Timber Press Inc., Portland, Ore.

Belsky, J.A. 1992. Effects of grazing, competition, disturbance and fire on species composition and diversity in grassland communities. J. Veg. Sci. 3:187 200.

Brooks III, J., M. Anderson, and P.J. Urness. 1984. Infrared reflectance analysis of forage quality for elk. J. Wildl. Manage. $48: 254-258$.

Coleman, S.W., F.E. Barton, and R.D. Meyer. 1985. The use of nearinfrared reflectance spectroscopy to predict species composition of forage mixtures. Crop Sci. 25:834-837.

Coleman, S.W., S. Christiansen, and J.S. Shenk. 1990. Prediction of botanical composition using NIRS calibration developed from botanically pure samples. Crop Sci. 30:202-207.

Coleman, S.W., J.W. Holloway, and J.W. Stuth. 1989. Monitoring the nutrition of grazing cattle with near-infrared analysis of feces. XVI Int. Grassl. Congr. 16:881-882. Nice, France

Garcia-Criado, B., A. Garcia-Ciudus and M.E. Perez-Corona. 1991. Prediction of botanical composition in grassland herbage samples by near-infrared reflectance spectroscopy. J. Sci. Food Agr. 57:507-515.

Leite, E.R. and J.W. Stuth. 1995. Fecal NIRS equations to assess diet quality of free-ranging goats. Small Ruminant Res. 15:223-230.

Lyons, R. K. and J. W. Stuth. 1992. Fecal NIRS equations for predicting diet quality of free-ranging cattle. J. Range Manage. 45:238-244.

Lyons, R.K., J.W. Stuth, and Jay P. Angerer. 1995. Technical note: Fecal NIRS equation field validation. J. Range Manage. 48:380-382.

Petersen J.C., F.E. Barton, W.R Windham, C.S. Hoveland. 1987. Botanical composition definition of tall fescue/white clover mixtures by near infrared reflectance spectroscopy. Crop Sci. 27:1077-1080.

Rumbaugh, M.D., D.H. Clark, and B.M. Pendery. 1988. Determination of root mass ratios in alfalfa-grass mixtures using near infrared reflectance spectroscopy. J. Range Manage. 41:488-490.

Volesky, J.D. and S.W. Coleman. 1996. Estimation of botanical composition of esophageal extrusa samples using near infrared reflectance spectroscopy. J. Range Mange. 49:163-166.

Walker, J.W. 1995. Viewpoint: Grazing management and research now and in the next millennium. J. Range Manage. 48:350-357. 